\title{
Correction to: Can Bicarbonate Enhance the Performance of Carob Seedlings Grown in Nutrient Solutions with Different Fe Concentrations?
}

\author{
Florinda Gama ${ }^{1}$ (1) Pedro José Correia ${ }^{1}$ - Teresa Saavedra ${ }^{1}$ - Susana Dandlen ${ }^{1} \cdot$ Amarilis de Varennes $^{2}$. \\ Gustavo Nolasco $^{1} \cdot$ Maribela Pestana $^{1}$
}

Published online: 10 December 2019

(C) Sociedad Chilena de la Ciencia del Suelo 2019

\section{Correction to: Journal of Soil Science and Plant Nutrition} https://doi.org/10.1007/s42729-019-00100-4

Readers should note that there was an error in this article as originally published:

Due to a typesetting error, numerous lines of text were missing, beginning after the first paragraph in Section 3.1 Experiment 1 and continuing through to the second paragraph of the section heading for Section 3.2 Experiment 2.

The original article has been corrected.

Publisher's note Springer Nature remains neutral with regard to jurisdictional claims in published maps and institutional affiliations.

The online version of the original article can be found at https://doi.org/ 10.1007/s42729-019-00100-4

Florinda Gama

fmgama@ualg.pt

1 MeditBio - Center for Mediterranean Bioresources and Food, Universidade do Algarve, Campus de Gambelas,

8005-139 Faro, Portugal

2 LEAF - Linking Landscape, Environment, Agriculture and Food, University of Lisbon, Tapada da Ajuda, 1349-017 Lisbon, Portugal 